\title{
History and Religion as Sources of Hellenic Identity in Late Byzantium and the Post-Byzantine Era
}

\author{
Georgios Steiris $(\mathbb{D}$ \\ Department of Philosophy, National and Kapodistrian University of Athens, 15703 Athens, Greece; \\ gsteiris@philosophy.uoa.gr
}

Received: 23 December 2019; Accepted: 22 January 2020; Published: 31 January 2020

\begin{abstract}
Recently, seminal publications highlighted the Romanitas of the Byzantines. However, it is not without importance that from the 12th century onwards the ethnonym Hellene (" $E \lambda \lambda \eta v$ ) became progressively more popular. A number of influential intellectuals and political actors preferred

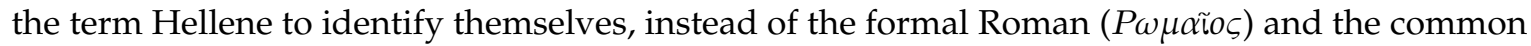

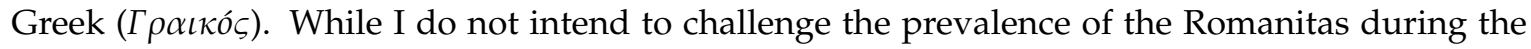
long Byzantine era, I suggest that we should reevaluate the emerging importance of Hellenitas in the shaping of collective and individual identities after the 12th century. From the 13th to the 16th century, Byzantine scholars attempted to recreate a collective identity based on cultural and historical continuity and otherness. In this paper, I will seek to explore the ways Byzantine scholars of the Late Byzantine and Post Byzantine era, who lived in the territories of the Byzantine Empire and/or in Italy, perceived national identity, and to show that the shift towards Hellenitas started in the Greek-speaking East.
\end{abstract}

Keywords: Romanitas; Hellenitas; Graecitas; Hellene; Greek; Byzantine Empire; identity; consciousness

\section{Introduction}

The question of Modern Greek identity is certainly timely (Steiris et al. 2016, p. vii). Recently, the Greek Minister of Education Niki Kerameus stated that History in primary and secondary school curricula "should be aimed at shaping national consciousness" (https:/www.keeptalkinggreece.com/ 2019/09/06/education-minister-history-textbooks/). Her comment caused a heated debate between rival political parties, because the question of what it means to be Greek today is of prime importance not only for academics but also for the entire Greek society. Two hundred years after the Greek war of Independence (1821), the discussion surrounding the so-called $\varepsilon \lambda \lambda \eta v \iota \kappa o ́ \tau \eta \tau \alpha$ (Greekness) is crucial. Although the term was introduced in 1851 by Constantine Pop (1816-1878), a Greek novelist, and was used extensively by scholars in the 1930s, there is no consensus on the conceptual content of the term (Tziovas 1989, pp. 31-38). There is a dispute whether, in order to define Greekness, we should focus on national consciousness or identity. In this paper, I shall adopt the analytical distinction between national consciousness and national identity according to Natia Tevzadze (Tevzadze 1994). She has argued that national consciousness refers to an inherent process of self-identification and absorption in a given community. It is an introverted and defensive mechanism of self-acknowledgement. Those who seek a national consciousness presuppose the existence of distinct cultural characteristics and genealogies, i.e. a mix of history, memories and sentiments that people are called to adopt. Consequently, those who perceive Greekness as a kind of consciousness presuppose likeness and identification. On the other hand, national identity is based on the sum of differential characteristics, such as otherness, the sum of features that differentiate a nation from others (Gellner 1983, pp. 6-7; Tevzadze 1994, pp. 437-40). This is an extroverted process of hetero-identification. National identity is a cultural or institutional 
construction, which is rather fluid. As a result, consciousness and identity represent two different approaches on nations.

As well as the term Greekness, I would like to propose the term Hellenitas to describe the ethnocultural identification with ancient Greeks that appeared in Late Byzantium. I deem the introduction of this term necessary, as I contend that Hellenitas is different from Graecitas, the self-identification

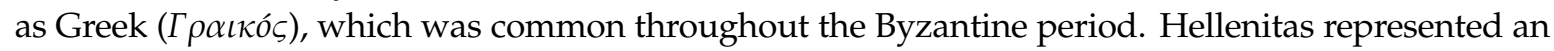
attempt to create a new connection with the ancient Greeks that stressed the emphasis to the most illustrious period of Greek antiquity, from the Greco-Persian wars until Alexander the Great, in an attempt to assist the Greek-speaking population of the Eastern Roman Empire, the so-called Byzantine, to regain their pride, when the Westerners disputed their Romanitas. Vacalopoulos' thesis, according to which the origins of Greek nationhood are to be traced to the Late Byzantium, since the sack of Constantinople and the partition of the empire after 1204 did instill the idea of a Greek "nation" in Byzantine hearts and minds, serves as the starting point of my views on Hellenitas (Vacalopoulos 1970). Contrariwise, Graecitas was a different notion, established during the long Roman period, focusing on the diachronic presence of the Greeks as a populus and not as a genos or nation. Meanwhile, Graecitas represented an attempt to undermine whatever would be connected with the pagan element of the ancient Greek culture. There is no evidence that the ethnonym Graeci signified any kind of self-identification with the ancient Greeks. It was an identity, which could easily coexist with Romanitas, while Hellenitas represented largely a break with Romanitas. Romanitas is a set of political and cultural concepts by which the inhabitants of the Eastern Roman Empire attempted their identification with the ancient Romans in the broad context of the translatio imperii.

My aim is not to discuss common views on a supposed diachronic Hellenic identity or consciousness (Vryonis 1978, pp. 237-56). To the contrary, I intend to show that, predominantly from the 13th to the 16th century, Byzantine scholars attempted to recreate a collective identity based on cultural and historical continuity and otherness (Vacalopoulos 1970, pp. 126-35). To my view, they shared common memories and cultural traits and they felt a connection with Greece (the territory, the memory and the ideal) as their homeland. Despite the fact that this endeavor took place before modernity, I claim that it was a discussion focused primarily on identity and not on consciousness, as the majority of modern scholars would expect. During the late Byzantine centuries, a major shift occurred in the East, and prominent members of the Byzantine intelligentsia challenged Romanitas and Graecitas in order to revisit their collective identity.

In my view-since I accept the ethno-symbolist approach, according to which the pre-modern ethnic views contributed heavily to the configuration of modern national identities-the debate about Hellenitas in Late Byzantium proves that the Byzantine intelligentsia sought to shape a proto-national community (Smith 1991, pp. vii-x; Smith 1995, pp. 3-23; Smith 2004, pp. 33-61; Smith 2005, pp. 404-15; Smith 2009, pp. 23-59). Their goal was a new nationhood, the identification with a community culturally and territorially circumscribed (Stouraitis 2018, p. 126).

In these terms, I attempt to scrutinize the ways Byzantine scholars of the Late Byzantine and Post Byzantine era, who lived in the territories of the Byzantine Empire and/or in Italy, perceived national identity, and to challenge Lamers's views (Lamers 2015) by showing that the shift towards Hellenism started in the Greek-speaking East. The Byzantine scholars attempted to redefine their identity based on the ethnonym Hellene ('E $\mathrm{A} \lambda \eta \nu$ ), a common cultural and historical awareness, Hellenic language, and their perceived otherness predominantly from the Latins and the Turks (Smarnakis 2015, pp. 222-25). My aim is to show that the Late Byzantines used the Hellenic label in an ethnic way, as they did not afraid to refer to the Hellenic $\gamma \varepsilon \dot{\varepsilon} \vee \varsigma$ or $\varepsilon^{\prime} \theta \vee o \zeta$, despite the ambiguities of the terms in the pre-modern period. Kaldellis argued, "the Byzantines' view of their own Roman identity was a national one, making Byzantium effectively a nation-state. Being a Roman was premised on common cultural traits, including language, religion, and social values and customs, on belonging to the $\varepsilon$ ' $\theta$ vo $\varsigma$ or $\gamma \varepsilon$ v $v o \varsigma$ on that basis, and on being a 'shareholder' in the polity of the Romans" (Kaldellis 2017, p. 173). On the contrary, Stouraitis held that the Roman identity pertained 
to an intellectual and political elite in Constantinople (Stouraitis 2014, pp. 175-220). While Kaldellis criticized Stouraitis's argument and presented a rather persuasive defense of his position, I think that Stouraitis's argument is more accurate regarding Hellenitas in Late Byzantium and the Post-Byzantine era. Taking Stouraitis's view as a starting point, I would like to support that principally in the 15th century the intellectual elite shifted, for several reasons, towards a Hellenic identity. Kaldellis anyway agreed that Hellenitas was an elite pursuit (Kaldellis 2017, p. 197). Although the elites used the ethnonym in other instances and not just for themselves, I admit that there is no evidence so far that Hellenitas was a movement embraced by the masses. However, I would like to revisit dominant views, in contemporary Greek and international bibliography, according to which the modern Greek identity was a byproduct of the Age of Enlightenment and represented a major departure from the previous tradition (Kitromilides 2009, pp. 21-32; Myrogiannis 2012, pp. 83-130). This article expands and supplement my views that were initially presented a few years ago (Steiris 2016, pp. 173-99).

\section{Modern Scholarly Debate on National Identity in the Late Byzantium}

Kaldellis recently summarized the modern scholarly debate by asking the question "Who were the Byzantines, then?" (Kaldellis 2019, pp. 29-32). Seminal publications shed more light to the discussion, attempting to reinterpret and highlight the Romanitas of the Byzantines (Constantinidou and Lamers 2019, pp. 1-25; Kaldellis 2007; Kaldellis 2019; Page 2008; Rapp 2008, pp. 27-147; Smythe 1996, pp. 26-36). It is common knowledge that the official appellation of the inhabitants of the Eastern Roman Empire was Romans even after the fall of Constantinople. However, it is not without importance that from the 12th century onwards the name Hellene ("E $E \lambda \eta \eta v$ ) became progressively more popular. A number of influential intellectuals and political actors preferred the term Hellene to identify themselves, instead

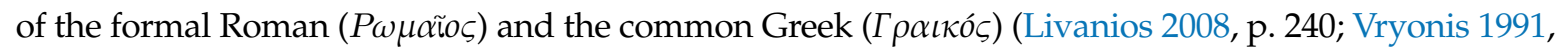
pp. 5-14). According to the prevalent view of modern scholarship, the shift should not be interpreted only as a statement of proto-nationalism but also as the outcome of growing archaism (Hobsbawm 2012, pp. 46, 59, 71-77). As Vryonis pointed out, the historian Critobulus (ca. 1410-ca. 1470) used to call the Balkan nations with their archaic names: Byzantines became "Hellenes", Albanians became "Illyrians", etc. (Vryonis 1991, p. 7). Laonikus Chalkokondyles (ca. 1430-ca. 1465), the prominent Late Byzantine historian, had the same approach (Akışık-Karakullukçu 2013, pp. 101-2). The same tendency was observed in Western Balkans and Central Europe. Bibliography on Byzantine Hellenization is extensive (Beaton 2007, pp. 76-95; Kaldellis 2017, pp. 173-210; Akışık-Karakullukçu 2019, pp. 1-30; Magdalino 1991; Page 2008; Papadopoulou 2015; Rapp 2008, pp. 127-47; Smarnakis 2015, pp. 211-34; Stouraitis 2017, pp. 70-94; Stouraitis 2018, pp. 123-39; Vryonis 1999, pp. 19-36). Furthermore, in lamenting the decline of their Empire, Byzantines tended to compare their sad present to the glory of ancient Greece (Ševčenko 1961, p. 173). In this context, it is noteworthy that Byzantine scholars, who fled to Italy, deliberately chose to

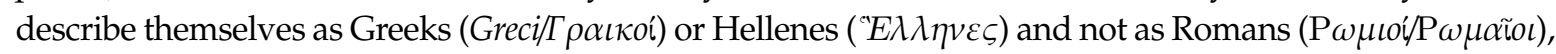
according to the Byzantine official terminology. While I do not intend to challenge the prevalence of the Romanitas during the long Byzantine era (Kaldellis 2007, p. 349; Kaldellis 2019, pp. 3-80), I suggest that we should reevaluate the emerging importance of Hellenization in the shaping of collective and individual identities after the 12th century. Collective identity is the awareness from which individuals in a social group derive values and worth (Abrams and Hogg 1990, p. 2).

Lamers-while acknowledging the shift towards "Greekness" - held that it started and flourished in Italy, among the Byzantine scholars who fled there in the 15th century (Lamers 2015, p. 1). Lamers makes a distinction between Greekness-the ethnocultural identification with the ancient Greeks-and Hellenism, the study and imitation of ancient Greek culture (Lamers 2015, pp. 2-3). While Lamers's viewpoint is interesting, I contend that the shift towards the Hellenitas started in the Greek East, rather than being a product of the Greek community in Renaissance Italy. For example, Scholarius (ca. 1400-ca. 1472), an illustrious philosopher and Patriarch of Constantinople, and Pletho (ca. 1355-1454), the legendary Platonist of Mystra, should not be considered as members of the Greek intelligentsia in Renaissance Italy. Moreover, the discussion about Hellenitas, as an identity feature, had started long 
before the 15th century. As a result, I hold that Lamers's argument is partial, overestimating the role of Greek scholars in Italy (Lamers 2015, pp. 270-72). Akışık-Karakullukçu-referring to Pletho-admitted that in the 15th century there was "an ongoing conversation on identity that was anchored in the politically fragmented world of the eastern Mediterranean" (Akışık-Karakullukçu 2019, p. 15). This conversation, in which Pletho participated, was introduced even before the 15th century, due to the obvious decline of the Eastern Roman Empire. Furthermore, Lamers's and Akışık-Karakullukçu's insistence to separate the community of the Greek scholars in Italy, which, according to them, was oriented towards Hellenitas, from the community of Greek scholars in the Ottoman regions, which was attached to Romanitas, is not based on stable ground, since we know that, in the 15th and 16th century, scholars traveled extensively and did not cut their ties with mainland Greece and the Minor Asia. In addition, they exchanged views and texts with their fellows, no matter where they stayed. In the following pages, we will have the opportunity to realize that, despite of their whereabouts, Late Byzantine scholars shared a genuine interest on Hellenitas. For example, Theodorus Gaza (ca.1398-ca. 1475), a seminal Aristotelian of the 15th century in Italy, was closer to Scholarius's views and did not share Cardinal Bessarion's (1408-1472) philosophical viewpoint.

\section{Mid-Byzantine Views on Identity and Consciousness}

After the 6th century AD, the Christianized Greek populations around the Mediterranean avoided to identify themselves as Hellenes ( $" E \lambda \lambda \eta v \varepsilon \varsigma$ ) since the term denoted the pagans. The formal Roman $(P \omega \mu \alpha \check{\imath} \varsigma)$ and the common Greek $(\Gamma \rho \alpha \iota \kappa o ́ \varsigma)$ became the standard appellations. The first was common among the inhabitants of the Eastern Roman Empire, while the latter served to separate the Greeks from people without Greek origin, without any identification with the ancient Hellenes (Svoronos 2004, pp. 54-62; Stouraitis 2018, p. 29). The historian Priscus (5th century) referred to

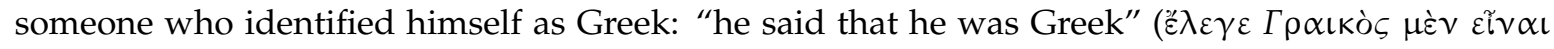

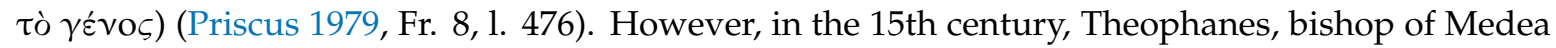
(1467-1474) and skilled rhetorician, was annoyed by the fact that Pope Eugenius IV called the Orthodox delegates in the Council of Ferrara of Florence (1438-1439) Greeks (

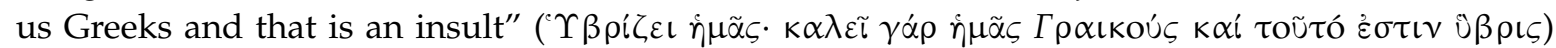
(Laurent 1971, p. 124). Furthermore, the historian Ducas (ca. 1400-ca. 1462) characterized the supporters of the Union of the Orthodox and Catholic Churches as priests of the Graeci $(\Gamma \rho \alpha \iota \kappa o$ i $)$ (Smarnakis 2015, p. 222). Cassius Dio (ca. 155-ca. 235), a statesman and historian of Greek and Roman origin, and the historian Procopius (ca. 490-ca. 565) also mention that the Romans used the term Graecus to degrade the Hellenes (Papadopoulou 2007, p. 219). Despite Theophanes's furor, the Latin-speaking elites of the West, from the 9th century onwards, called the Byzantines Greeks and not Romans, predominantly for political reasons. Namely, they attempted to dispute the Byzantine Emperors' claims to the Roman legacy. After the 12th century, Graecus refers predominantly to someone of the Orthodox faith.

During the reign of the Comneni (1081-1204), the term Hellene regained progressively its prominence (Kaldellis 2007, pp. 283-300). It signified people of Greek origin, who also shared a common Hellenic education, meaning classical education. John Tzetzes (ca. 1110-ca. 1180), a Byzantine

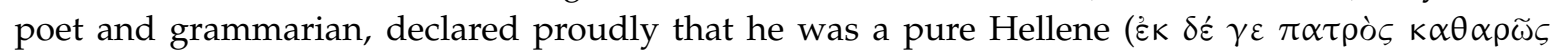
$\left.\tau v \gamma \chi \alpha \dot{v} \sigma o v \tau \alpha{ }^{\circ} \mathrm{E} \lambda \lambda \eta \vee \alpha\right)$ (Tzetzes 1972, Ep. 6, 10.5). In an anonymous text of the same century, the

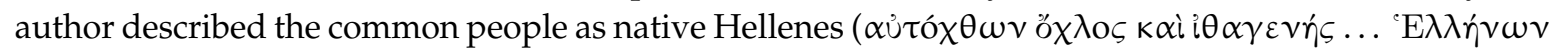
$\tau \widetilde{\omega} v \dot{\alpha} \pi \alpha v \tau \alpha \chi 0 \tilde{\cup})$ (Romano 1974, 1.117-118). Another passage of seminal importance is found in a letter written by John III Ducas Vatatzes (ca. 1193-1254), Emperor of Nicaea, and addressed to the Pope.

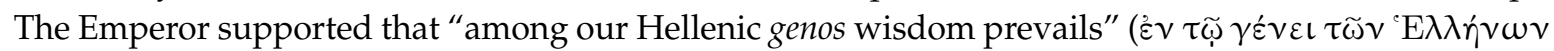
$\dot{\eta} \mu \widetilde{\omega} v \dot{\eta} \sigma o \varphi i \alpha \beta \alpha \sigma \iota \lambda \varepsilon \cup ́ \varepsilon \iota)$ (Krikones 1988, 1.178-186). His son and Emperor Theodorus II Ducas Lascaris (1222-1258) also felt a cultural and genealogical connection with the Hellenes. He proudly stated that philosophy belongs to Hellenes. Furthermore, in the first person plural, he claimed that the 
Hellenes were the fathers of all sciences. The ancient Hellenes and the Hellenes of Theodorus's era breathed the same air and shared the same language and blood: (Festa 1898, CIX, 1. 48-49).

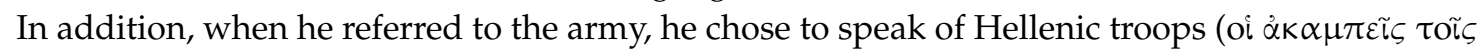

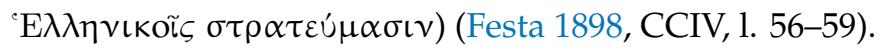

It is obvious that Vatatzes's shift towards Hellenitas was pushed onto by the Latins (Kaldellis 2007, p. 371). Theodorus Metochites (1270-1332), a Byzantine statesman and philosopher, in a sermon at court, asked the Emperor Andronicus III Palaeologus (1259-1332) to save the Hellenes (Metochites 1996, p. 38-40; Metochites 2007, pp. 128-420). Later, in the Chronicon Morae (14th century) we read that the inhabitants of the Eastern Roman Empire, the so-called Romans, tenaciously preserved

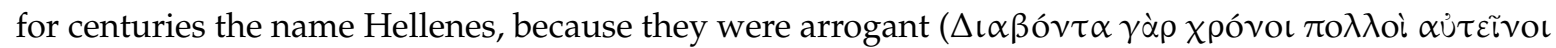

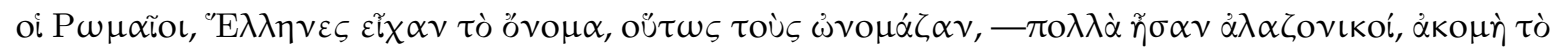

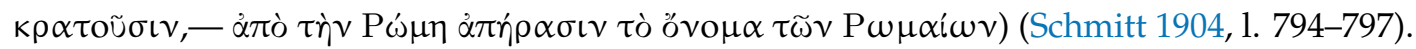

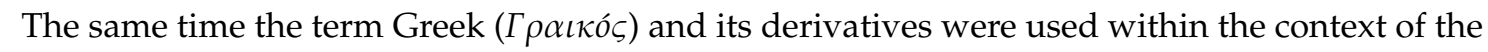
conflicts between members of the Orthodox and the Catholic faith (Papadopoulou 2014, pp. 172-73). After 1204, Byzantine Romanitas received a serious blow. As a result, the emphasis on Hellenic ethnocultural identity was an interesting alternative for the ruling elites (Stouraitis 2017, pp. 85-86). Kaldellis remarked that Hellenitas, after 1204, "no longer revolves around high culture but has moved down the social scale. Linguistically, "Hellenes" are now no longer those who have mastered Attic rhetoric but those whose language is Greek" (Kaldellis 2007, p. 368).

\section{Hellenitas in 15th Century Byzantium: from Chrysoloras to Pletho}

\subsection{The Conciliatory Stance}

At the turn of the 15th century, Manuel Chrysoloras (ca. 1350-1415), a seminal Byzantine scholar who contributed to the spread of Greek literature in Renaissance Italy, referred to the twofold identity of the Byzantines, highlighting the Hellenic and the Roman elements. The Byzantines would equally trace their heritage to the ancient Greeks and the Romans. Chrysoloras admitted that the Byzantines forgot their original name and adopted the ethnic name Romans. Despite his efforts in favor of shared identity, his conciliatory stance was not popular. Hellenization gradually gained ground among the Byzantines elites. Namely, Chrysoloras, in an epistle (1414) to the Emperor Manuel Palaeologus (Patrinelis and Sofianos 2001, p. 117, II. 4-13), stated:

Let us remember from what men we are descended. If someone would like, he could say that we descended from the first and age-old, I mean from the most venerable and ancient Hellenes (no one has remained ignorant of their power and wisdom). If you please, you could also say that we descended from those who came after them, the ancient Romans, after whom we are named and who we are now named and who we, I suppose, claim to be, so that we even almost erased our ancient name. Rather both of these races came together in our times, I think, and whether someone calls us Hellenes or Romans, that is what we are, and we safeguard the succession of Alexander and that of those after him (Lamers 2015, p. 32).

Chrysoloras entitled this part of his text Exhortation on behalf of the genos. Chrysoloras suggested that the Emperor revive the study of ancient literature, both pagan and Christian. He added that the Byzantines should not neglect their cultural inheritance, all the while the Italians were meticulously studying Greek texts (Patrinelis 1972, p. 501).

A few years later, namely in 1429, Isidore (1385-1463)—bishop of Kiev, humanist and theologian who promoted the Union of Orthodox and Catholic Christendom—entertained similar views. The Eastern Empire had two constitutive elements: the Hellenic and the Roman. He praised the Emperor Constantine the Great for mingling and uniting the best of the Romans with the best of the Hellenes, creating the

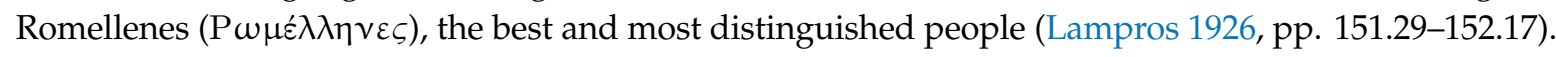
Not long after, Makarius Melissinus (d. 1585), bishop of Monemvasia, referring to the speech of Constantine XI Palaeologus (1405-1435) just before the fall of Constantinople, attested that the Emperor 
addressed the people as descendants of the Romans and the Hellenes (Grecu 1966, pp. 414.21-420.33). However, Chrysoloras's and Isidore's syncretism was not popular in the next centuries and the shift towards Hellenitas was further reinforced.

\subsection{Pletho's Radical Hellenitas}

It is well documented that in the 15th century several intellectuals and political figures among the Greek-speaking communities of Eastern and Western Europe chose intentionally the term Hellene

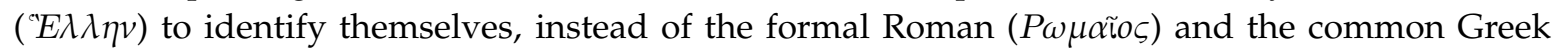

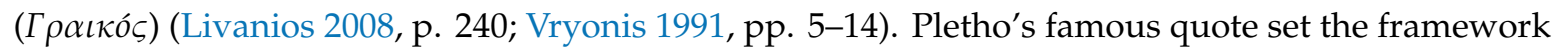
for those who investigate the shift towards Hellenitas in late Byzantium: "we, over whom you rule and hold sway, are Hellenes by genos, as is witnessed by our language and ancestral education" (Pletho 1926a, pp. 247.I.14-248.I.3). Pletho also stressed the continuity of the Hellenes by saying that they have always inhabited mainland Greece and no other people before them had inhabited the same area. It is obvious that matters of historical and geographical continuity are core identity issues (Pletho 1926a, 248.II.2-10). Pletho's insistence in autochthonism could also be interpreted as a byproduct of his classicism, since the ancient Athenians were also proud of their autochthony. Woodhouse's view (Woodhouse 1986) that Pletho was the last of the Hellenes is disputed and most modern scholars prefer to denounce him as the last of the Byzantines and the first and foremost Modern Greek (Linardos 2010; Geanakoplos 1984, p. 436; Hladky 2014, pp. 269-86; Nikolaou 1974, pp. 98-102; Peritore 1977, pp. 173-77; Svoronos 2004, p. 78; Bargeliotes 2009, pp. 44-61; Harris 2000, pp. 25-44). Pletho thought of the Hellenes as a genos with common culture, heritage and ancestral territory. Pletho's views on identity have been analyzed thoroughly in the last two centuries, namely his thoughts on genos, ethnos and homophylon (Garnsey 2009, pp. 327-40; Siniossoglou 2011, pp. 327-84; Siniossoglou 2014, pp. 415-31; Woodhouse 1986, pp. 79-118). Admittedly, it is difficult to understand the essence of these key concepts and it is rather challenging to shape a coherent understanding of his national consciousness and identity (Zakythinos 1932, pp. 365-76; Webb 1989, pp. 219-49). The terms are vaguely used and the texts do not allow us to provide definitions. Furthermore, Pletho was not always consistent. For instance, in Monodia in Helenam Palaeologinam, a public official speech, Pletho declared that the Byzantine Emperor reigned over the Romans (Pletho 1926b, p. 271).

In order to understand Pletho's contradictory views, I propose a different approach. Since identity is largely based on the internalization of otherness, we would better comprehend his Hellenism by analyzing his position concerning others, namely the Muslims and the Latins.

In his philosophical treatises, Pletho scorned the Arabic philosophers, particularly Averroes and Avicenna, on several occasions (Lagarde 1973, pp. 321.3-8, 322.36-38; Steiris 2017, pp. 309-34). It is obvious that he deliberately adopted an anti-Averroist approach, which was common, as many other, to 15th century European humanists. Whilst his criticism is not philosophically accurate, it served his broader anti-Muslim and anti-Latin agenda. He contended that medieval philosophers outside of the Greek-speaking world overrated the significance of the Arabic philosophical texts. Pletho held that the Arabic and Scholastic scholars did not properly understand ancient Greek philosophy and distorted it (Mavroudi 2013, pp. 198-99). Pletho urged his fellow Byzantine scholars to rely on the Greek philosophical tradition-especially Platonic and Neoplatonic-and condemn the Scholastic's Aristotle. It is well known that in 14th century Byzantium, a circle of scholars around the Cydones brothers-Prochorus and Demetrius - translated and commented on Aquinas's and other Scolastics' texts in order to promote a different philosophical approach among the Orthodox. In the 15th century, Georgius Scholarius, Pletho's principal opponent, continued on the same path and further promoted Thomism. Pletho felt contempt for Aristotelian philosophy, which he considered inherently problematic, and he was annoyed by the prevalence of Aristotelianism among the Muslims and the Latins. Pletho did not aim at a detailed study of Arabic philosophy and its Jewish and Latin interpretations. He agreed with the view that ancient Greek philosophy was preserved only in Byzantium (Karamanolis 2002, 
pp. 260-63). Hence, Pletho's Hellenitas was a key element in his effort to safeguard the Hellenes from the expansion of Latin culture in the Greek speaking East.

\section{The Next Generation: In the Footsteps of the Giants}

Laonikus Chalkokondyles followed Pletho's example by considering Hellenism a cultural and political identity (Vacalopoulos 1970), although he did not hesitate to apply the name Hellene to Orthodox Christians (Akışık-Karakullukçu 2013). He studied with Pletho in Mystra and he became one of the most important historians of the 15th century. He thought of the Byzantines as Hellenes and rejected any kind of Romanitas:

[They] guarded their (Hellenic) language and customs until the very end because they (Hellenes) were much more numerous than the Romans. However, they (Hellenes) no longer called themselves according to their (Hellenic) hereditary tradition and the name was changed. And, thus, the Emperors of Byzantion were proud to call themselves Emperors and Autocrats of Romans and never found it appropriate to be called Emperors of Hellenes" (Kaldellis 2014a, vol. 1, pp. 6-7).

The Greek-speaking inhabitants of the Eastern Roman Empire were Hellenes, not Romans, despite the fact that the Emperor was officially called "Emperor of the Romans". Chalkokondyles consistently referred to the Byzantines as Hellenes. According to him, Romans are the followers of the Pope (Akış1k-Karakullukçu 2013, pp. 238-300). To the contrary, he considered equally

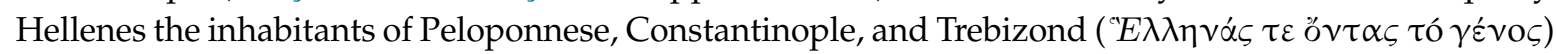
(Chalkokondyles 1922-1928, p. 219, II. 4-5, 248, II. 17-23), and aspired to a union of the Hellenes under a new Hellene king, who would govern them according to the Hellenic mores:

And the present fame of the Hellenic language will be greater in the future, when an Emperor will rule over a sizeable Hellene Empire and he will have imperial descendants. The children of the Hellenes will be attached to these emperors according to their own customs and will be ruled in a manner pleasing to them. And they will rule over others forcefully (Kaldellis 2014a, vol. 1, pp. 4-5).

It is also noteworthy that Chalkokondyles narrates the Greek history in a way that stresses the continuity of the Greeks. He saw the Byzantine period as another period of the long Greek history, which had nothing to do with the Romans (Chalkokondyles 1922-1928, p. 4, II.3-16). According to him, the Byzantines were Hellenes and preserved their culture during the centuries (Chalkokondyles 1922-1928, p. 4, II. 3-16). Moreover, he de-Romanized the Byzantines with the argument that besides officially calling themselves Romans, their language and religion differed (Kaldellis 2014b, pp. 171-96). Whilst Chalkokondyles's Hellenitas claims are bold, I would not agree with Akışı-Karakullukçu's argument, that "Laonikos is unique in the long and illustrious Byzantine historiographical tradition for having abandoned the traditional Roman identity and to have consistently referred to the protagonists of his narrative as Hellenes and to have located the Romans in the West since the time of Charlemagne, referring to the Papacy, the Carolingians, the Holy Roman Emperors, their political culture, and customs as Roman institutions" (Akışık-Karakullukçu 2019, p. 3). In fact Chalkokondyles was one among many others, who in the Late Byzantine centuries focused on Hellenitas. He was neither an exception nor an innovator, and his work presented a concrete narrative to support the claims about the continuity of the Hellenic genos.

Michael Apostolis (ca. 1422-ca. 1478), a faithful adherent of Pletho's philosophy and ardent copyist in Italy and Greece, supported similar views on the threat of cultural-hence, national-alienation. Apostolis held that Greek philosophy and Greek cultural tradition in general were in danger of alienation. According to Apostolis, Theodorus Gaza and some other members of Bessarion's circle did not respect the interpretative patterns of ancient Greek philosophy. Instead, they read it through the lens of the Scholastics, who misinterpreted and transformed the original thought of not only Plato and 
the Platonists but also that of Aristotle and his commentators. Apostolis shared Pletho's contempt for Latin philosophy (Apostolis 1967, pp. 159-69). Particularly, Pletho accused Scholarius that he followed the Averroistic Aristotelianism and neglected the Platonic philosophy, which represented the best aspect of Greek thought. Apostolis also disapproved of Scholarius's admiration for Aquinas (Scholarius 1936, p. 5.22-26; Scholarius, 1935, p. 153.23-24). It is noteworthy that, while Apostolis openly rejected Aristotelianism, he avoided relying on the Byzantine literature concerning the preponderance of Platonic or Aristotelian philosophy. Instead, he resorted to Pletho, Plato and several ancient commentators. Apostolis, as Pletho before him, preferred the ancient Greek texts and did not rely on Christian philosophy and his contemporaries. Pletho and Apostolis attempted to draw a line between Greek philosophy - which is purely Platonic — and Scholastic philosophy, which is attached to Aristotle and the Arabs. He was annoyed by the fact that the Latins thought of themselves as more important in comparison not only to the ancient Greek philosophers, namely Socrates, Pythagoras and

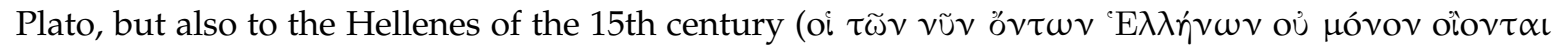

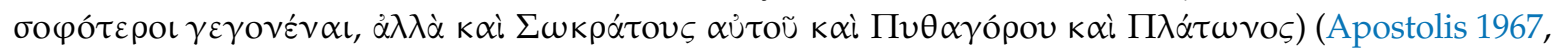
p. 168). Moreover, he did not hesitate to call himself and his contemporaries "sons of the Hellenes", without questioning the compatibility of Hellenism with Christian religion (Apostolis 1967, pp. 168-69). According to Apostolis, there was no dividing line between ancient and modern Greeks (Apostolis 1967, p. 168). Apostolis proudly declared that he is an offspring of the Hellenes and he followed in their path (Apostolis 1967, p. 169).

It is noteworthy that even Theodorus Gaza, Apostolis's main opponent, blamed his ancestors, the ancient Greeks, for being reluctant to accept the Roman calendar. Moreover, he accused them that they preferred to call themselves Romans, instead of Hellenes, a disastrous choice that was still in use in Gaza's times (Lamers 2015, p. 60). Gaza, as Pletho and Apostolis, considered the cultural alienation caused by Latin influences in both antiquity and Late Middle Ages as a major threat for Hellenism. Furthermore, Gaza's associate Nikolaos Sekoundinos (1402-1464) emphatically stressed that the Byzantines were sons of the Hellenes and imitated their ancestors (Boissonade 1833, v.5, p. 386).

Although Apostolis thought of himself as heir of the ancient Greek philosophers and his mother tongue gave him the opportunity to study the original Greek texts, it may be rather simplistic to interpret Pletho's and Apostolis' anti-Aristotelianism as a reaction of "Hellenism" against "Christianity" (Livanios 2008, p. 267). It is well known that Pletho was an anti-unionist and did not hesitate to support the Orthodox position in the council of Ferrara-Florence against the Latins (Kyros 1947, v.1, pp. 103-7; Laurent 1971, pp. 366.29-368.7). Pletho and Apostolis did not aim to confront Christian religion. They aimed at the refusal of the imperialism of Latin culture, which threatened to alienate the Greeks. Cultural opposition to the Latins and the Turks was the only way to safeguard the Hellenic genos from extinction (Siniossoglou 2014, p. 418). It is noteworthy that Apostolis complained to Bessarion that his compatriots in Crete did not send their children to his school because they were afraid of turning them to Romellenes (Stefec 2010, pp. 129-48). It is obvious that cultural alienation was somehow connected to religious and ethnic identity in 15th century Crete.

On the other hand, whilst modern research thought of Georgius Scholarius as a proponent of Orthodoxy, he did not unconditionally disapprove of Hellenism (Livanos 2004, pp. 23-40). It is well known that in a dialogue with a follower of the Jewish faith, Scholarius replied to the hypothetical question "Who am I?" by stating that he considered himself to be a Christian. Whilst he spoke the Greek language, he claimed that he did not think like the Hellenes (Scholarius 1930, p. 253). Scholarius's response obscure his views on identity and consciousness. Namely, he frequently considered himself and his fellow Byzantines as "Hellenes" and their motherland as "Hellas" (Angelou 1996, pp. 1-19). Moreover, he admitted that he and his compatriots were offspring of the Hellenes (" $E \lambda \lambda \dot{\eta} v \omega v \gamma \alpha \dot{\alpha} \rho$ $\dot{\varepsilon} \sigma \mu \varepsilon \dot{\varepsilon} v \pi \alpha \tilde{\imath} \delta \varepsilon \varsigma^{\prime \prime}$ ) (Scholarius 1930, p. 13) and Constantinople was the motherland of the Hellenic genos

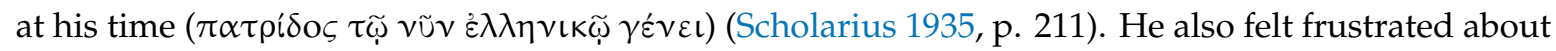
the possible extinction of the Hellenic genos because the Hellenes were the best among the human 
race (Scholarius 1928, p. 285). Moreover, the Hellenic genos prevailed in wisdom and lawfulness. The Hellenes were the best among the rest of the human races (Scholarius 1928, p. 285).

Scholarius, contrary to Pletho and his followers, did not share his skepticism towards Latin philosophy (Livanos 2006, pp. 74-86). He did not refrain from comparing Scholastic philosophy to ancient Greek, since he appreciated the progress made in Western Europe after the end of antiquity (Scholarius 1928, p. 386; Scholarius 1935, p. 406). Scholarius dedicated a large part of his career studying and commenting on works of major Scholastics, because he appreciated the originality of Latin thinkers. He was persuaded that the diffusion of Latin philosophy would benefit the Greeks, because the Latins further developed ancient Greek philosophy (Scholarius 1928, p. 386; Scholarius 1935, p. 406). Therefore, Scholarius did not share Pletho's fear of cultural alienation of the genos; his fears concentrated rather on the physical extinction of the genos (Scholarius 1935, pp. 406-7). Scholarius supported that the Byzantines should not exclusively study the ancient Greeks. Instead, they ought to study and incorporate the enhanced version of Greek philosophy that the Latins would offer them. Scholarius did not reject Hellenitas on grounds that have nothing to do with Christian religion. It seems that he felt a connection with the Hellenes of classical antiquity and thought of himself as a Hellene, besides a Christian and a Roman. However, he did not perceive Hellenitas as an imitation of classical antiquity. Rather, he aimed at an upgraded Hellenism, enriched by the best aspects of the Latin culture. Scholarius's views prove that Lamers's argument-according to which "the Hellenic identifier was used especially by Byzantine Latinophrones, who often settled in the Latin West or in the Latin-ruled parts of the Greek-speaking world" (Lamers 2015, p. 31)—is not accurate. Scholarius was the leading figure of the anti-Unionist party and he served the Ottoman rulers after 1453.

Nonetheless, the discussion of Greek consciousness and identity in the 15th century should not be limited to Pletho's entourage and his rivals. There is a rather interesting confrontation between Georgius Trapezuntius (1395-1472), a renowned translator and Aristotelian of the 15th century who migrated to Italy, and Cardinal Bessarion, who studied in Mystra with Pletho and then became a Cardinal in the Papal Curia. Despite his first Platonic steps in philosophy (Hankins 1990, p. 180; Geanakoplos 1989, p. 55; Gilbert 1968, pp. 463-500; Monfasani 1976, pp. 18-19, 73, 102, 167-68; Monfasani 2002a, pp. 220-21; Syros 2010, pp. 473-77), Trapezuntius gradually became the strongest critic of Plato and a fervent defender of Aristotle (Monfasani 1976, p. 19). His most influential book was Comparatio Philosophorum Platonis et Aristotelis (1458). In his work, Trapezuntius attempted to provide an explanation of how he came to disown Plato and become a supporter of Aristotle (Kristeller 1972, pp. 86-109; Monfasani 1976, p. 201; Monfasani 2002b, pp. 179-202). Trapezuntius occasionally refers to ancient Greece in ways that allow readings related to issues of consciousness and identity. Namely, he expressed his disapproval of Plato's attack to the four liberators of Greece, namely Miltiades, Themistocles, Pericles and Cimon (Trapezuntius 1523, O5r-P2r). In his dialogue Gorgias Plato sketches out a scornful Socrates against Themistocles, Cimon and Miltiades because did not care to properly educate the Athenian people when they were in power. According to Socrates, these four politicians recklessly filled the city with projects without any concern for the citizens and their education (Plato, $503 c-519 e)$.

Trapezuntius discussed the same subject in a chapter entitled On Plato's hatred and attack of Plato over of the four saviors of Greece (Trapezuntius 1523, O5r-P2r). He felt discomfort for the scale of ingratitude and hatred of Plato against the saviors of Greece (Trapezuntius 1523, O5r). Trapezuntius was furious because Plato did not find any other reason to write about the liberators of Greece, except only to blame them. In order to defend Miltiades, Trapezuntius stated: "For those who saved our country and forefathers, saved us as well" (Trapezuntius 1523, O6v). It is evident that he felt a connection with the ancient Greeks and considered them as his ancestors. Moreover, he admitted that they saved the Greek genos, when he projected the consequences of the four liberators' actions up to his epoch. Trapezuntius was proud of his Greek roots and he treated the Persian wars proportionally to the Turkish threat (Trapezuntius 1523, O6v). It is indicative of the way Trapezuntius perceived the Greco-Persian wars that-in his exhortation (1452) to Pope Nicholas V (Monfasani 1984, p. 435)—he compared them 
to the threat posed by the Turks to the Byzantine Empire and Christian Europe during his times. Trapezuntius considered the Platonic text to be dangerous because it was able to challenge the moral of the Greeks who, at the same time, were threatened by the Turks (Monfasani 1984, pp. 435-42). It is noteworthy that Trapezuntius conceptualized the combat between Turks and Christians through the lens of the ancient Greek historian Herodotus, as Chalkokondyles did (Akış1k-Karakullukçu 2013, pp. 189-94). Furthermore, when Trapezuntius referred to Greece, he chose the word patria. In my view, the word patria enhances the bonds of the Greeks of antiquity to the Greeks living during the end of the Byzantine Empire, because there is a sense that they shared something. Moreover, Trapezuntius's interpretation of ancient Greek history and his parallelisms with the dangers that the Greeks faced in the 15th century, proved his sense of connection to the Greek past.

In the exhortation to Pope Nicholas V, which he wrote in order to motivate the Latins to help repel the Turks, Trapezuntius identified himself as Graecus and Christianus (Monfasani 1984, p. 435). It is obvious that he does not perceive the two terms as identical. A Graecus is not necessarily Christian, according to him. Trapezuntius clearly states that he did not adhere to the doctrines of the Greek Orthodox Church when he wrote the letter: someone could be Graecus without being Orthodox. Trapezuntius's reference questions Angelou's argument that the word 'Hellene' in the 15th century means "Greek Orthodox" (Angelou 1996, pp. 1-19). Trapezuntius's reference is accompanied by the identification with Christianity and reflects his perspective. While elsewhere in this same letter, as

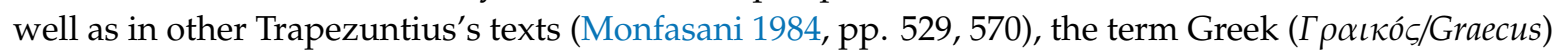
seems to indicate the Orthodox, the above passage from the preface clearly distinguishes the national

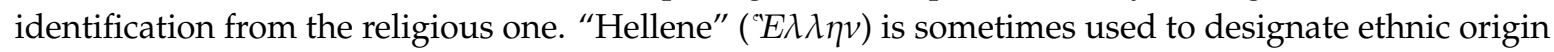
(Monfasani 1984, pp. 539, 550), but also as a synonym of pagan (Monfasani 1984, p. 550). However,

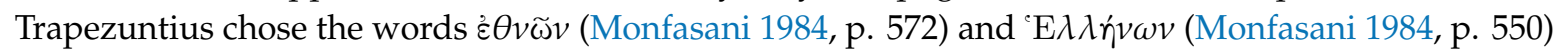
to refer to pagans (Monfasani 1984, p. 572). In addition, the term 'Av $\alpha \tau o \lambda \iota \kappa o$ ' (Orientals) is used for religious purposes (Monfasani 1984, p. 531). Trapezuntius's plea to the Pope to guarantee the salvation of Europe against the Turks is particularly interesting (Monfasani 1984, p. 435-42). He attempted to separate the Greeks from their Eastern neighbors and connected them to the fate of the "Catholic Europe". According to him, Greece and the rest of Europe share a common future. If Greece fell, the rest of Europe would follow. We should bear in mind that Greek scholars show a preference to words that mean West ('E $\left.\sigma \pi \varepsilon \dot{\varepsilon} \rho \alpha \varsigma,{ }^{\circ} \mathrm{E} \sigma \pi \varepsilon \rho i \omega v\right)$ in describing Europe.

Trapezuntius read ancient Greek history-especially the Greco-Persian wars-under a new spectrum and enthusiastically associates himself with the Greek past. He felt a connection with the ancient Greeks, a generis coniunctio in his own words (Monfasani 1984, p. 435). He also proudly declared that he belonged to the Greek genos (Monfasani 1984, p. 351). Trapezuntius perceives himself as a Greek, as a person connected to the Greek land and the Greek past. In his argument against the Italian humanist Andrea Agaso, Trapezuntius asserted that his opponent could not praise the ancient Greeks and despise modern Greeks. Trapezuntius's claim presupposes that the ancient and modern Greeks belong to the same genos (Monfasani 1984, p. 383, 393). At the same time, he declares that he is also a Christian, believing that someone who is connected and inspired by the Greek past can be a Christian, without one identity negating the other. He is concerned about two positions that created a synthesis which, in the eyes of Pletho, seemed to be at least strange. As a result, Siniossoglou's claim that "Byzantine humanists were Hellenes, not because they revived the religion of the ancients, but because they deviated from Orthodoxy by experimenting in varying degrees with 'pagan' philosophy and especially Platonism" (Siniossoglou 2011, p. 26) is untenable in view of Trapezuntius's own writings. Trapezuntius was a proponent of Hellenitas, despite the fact that he used frequently the term Graecus. His predilection was the result of the fact that he wrote the vast majority of his works in Latin.

Cardinal Bessarion replied to Trapezuntius's Comparatio in his own In Calumniatorem Platonis (1469). Bessarion sought to defend Plato from Trapezuntius's attacks (Mohler 1923-1942, v. III, p. 546). According to Bessarion, Plato did not discuss the military successes of these men. He expressed a judgement on whether they rendered the citizens better or they learned to win over themselves first 
and then their opponents. Bessarion's answer was that the four saviors were demagogues because they used the average, demagogic rhetoric with the intention to please rather than benefit the people (Mohler 1923-1942, v. III, pp. 546-48). He supported that Greece was not saved in the naval battles of Salamis and Artemisium; rather, it was rescued in the infantry battles of Marathon and Plataea (Mohler 1923-1942, v. III, p. 548). While the four liberators of Greece contributed militarily, they did not benefit their city on any other level. (Mohler 1923-1942, v. III, pp. 548-52).

In his magnum opus, the In Calumniatorem Platonis, Bessarion refers rarely to Greece and Hellenism. Bessarion intentionally keeps a distance from the topic under consideration. On the contrary, in a letter to the Emperor Constantine Palaeologus XI, Bessarion congratulates him personally and the Hellenes

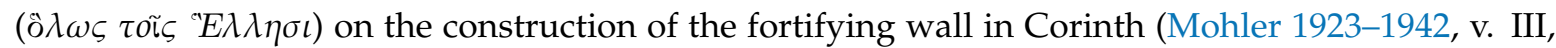

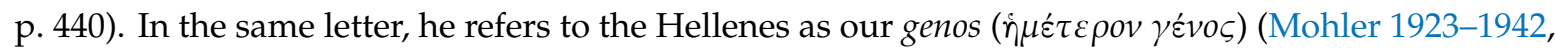
v. III, p. 547) and he declares that he is Hellene by genos (Mioni 1973, pl. XX). According to Bessarion, the Hellenes are a praiseworthy genos (Mohler 1923-1942, v. III, p. 445). Palaeologus had the privilege to rule the offspring of the people who defeated the Persians at the battle of Plataea (Mohler 1923-1942, v. III, p. 443). Moreover, he calls Pletho "the glory of Hellas" (Mohler 1923-1942, v. III, p. 469). Addressing Theodorus Gaza, Bessarion expresses his fear for the fate of the Hellenes, since the decline of education would lead to the extinction of Greek language and genos (Mohler 1923-1942, v. III, p. 486). Furthermore, in his treatise "In illud evangelii: Sic eum volo manere, quid ad te?", Bessarion names

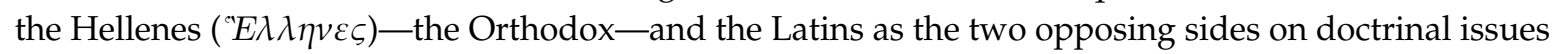
(Mohler 1923-1942, v. III, pp. 70-87). According to Bessarion, someone could be Hellene and Orthodox at the same time. This is a major departure from Pletho's interpretative scheme. Finally, he presented the history of Trebizond as a direct line from classical Athens to his times (Bessarion 1984, pp. 3-75). In his Encomium to Trebizond, he stressed the continuity of the Hellenes, both ethnically and culturally.

Bessarion, when addressing a Greek audience, preferred the ethnonyms Hellenes and Graeci, in opposition to the Latins and Romans of the Western Europe. Graeci was used mainly in religious contexts. Whilst Bessarion was not preoccupied against the Latins, he shared Pletho's fear about the future of the Hellenes, and the potential cultural alienation of his compatriots. As a reaction to this, he established his famous library, he collected manuscripts and hired scribes to safeguard the continuity of the language and values (Mohler 1923-1942, v. III, p. 479).

From his part, Andronicus Callistus (ca. 1400-1476), a professor of Greek language in several European cities and Bessarion's associate, also called the Byzantines Hellenes (Migne 1866a, p. 1020; Migne 1866b, p. 1131). Arsenius Apostolis (1465-1535), bishop of Monemvasia and son of Michael Apostolis, Marcus Musurus (1470-1517), a Cretan publisher and famous humanist in Venice, and Janus Lascaris (ca. 1445-1534), a noted Greek scholar in Renaissance Italy, followed the same path (Lamers 2015). Along the same lines, Christopher Kontoleon (first half of the 16th century), a scribe and scholar, argued that his compatriots would never improve as long as they prefer to use the ethnonym Romans instead of Hellenes (Lamers 2015, p. 58). We should admit that this is a rather quick escalation of Hellenitas. While all the aforementioned scholars discussed identity and consciousness predominantly on cultural and political grounds, Michael Tarchaniota Marullus (1453-1500)—a poet, soldier and humanist -put forth the concept of the bloodline. Namely, in one of his poems he wondered about the glory of the Pelasgian blood. He held that the survival of the Greek language was the only way to preserve the glory of the Pelasgian blood (Lamers 2015, p. 211). It is noteworthy that he chose to refer to Greeks with a rather obsolete term. Nevertheless, he felt that the connection with ancient Greeks is also biological and not only cultural. Therefore, Marullus considered the Byzantine Empire as an Hellenic empire. Hellenes possessed the Imperium Romanum for centuries (Lamers 2015, p. 221).

Finally, John Argyropoulos (ca. 1405-1487)—a leading Aristotelian of the 15th century in Italy (Steiris 2015)—was a fervent supporter of Hellenitas. His approach includes the continuity of Hellenism from antiquity to his epoch (Runciman 1985, p. 120). Namely, he stated to the Emperor Constantine Palaeologus XI that his kingship should be in advantage of the Hellenic genos and the common

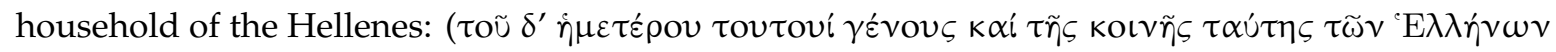




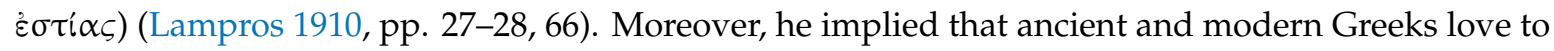
reflect on their passions; they are emotional (Lampros 1910, p. 10). Argyropoulos's views are better described in an oration addressed to the Emperor John VII Paleologus (1392-1448) (Lampros 1910, pp. 1-7). In this oration, he frequently refers to the inhabitants of the remaining Eastern Roman Empire

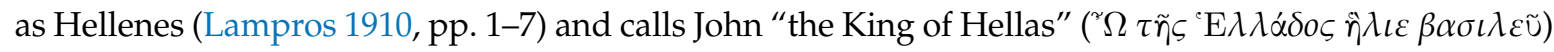
(Lampros 1910, p. 7). After the Emperor's death, Argyropoulos praised the late Emperor for managing to save the lands, the cities and the language of the Hellenes (Lampros 1910, p. 6). According to Argyropoulos, Constantine XI Paleologus, the last Byzantine Emperor, was, like his predecessor, also king of the Hellenes (Lampros 1910, pp. 29, 37, 47). Argyropoulos did not hesitate to identify himself as a Hellene (Lampros 1910, pp. 30, 66). In addition, he repeatedly interpreted the historical events of his times in connection to the ancient Greek history. Argyropoulos's works are characterized by an intense patriotism, which is in fact a type of Hellenism different from that of Pletho. Although Argyropoulos shared with Pletho a strong archaism (Lampros 1910, pp. 7, 32, 36, 41, 44), he did not oppose the genos of the Hellenes to the Orthodox dogma and remained a Christian, even a Catholic (Lampros 1910, pp. 22, 35; Monfasani 1992, pp. 56-57).

\section{Conclusions}

In conclusion, Greek scholars in Late Byzantium and the Post-Byzantine era contributed to the quest of a Greek identity by synthesizing various elements in the formation of Hellenitas. Namely, Pletho and Apostolis aimed at the refusal of the imperialism of Latin culture in order to safeguard the genos. Scholarius felt a connection with the Hellenes of classical antiquity and thought of himself as a Hellene, not just a Christian and a Roman. However, he did not approve of the idea of Hellenism as an imitation of classical antiquity. Rather, he aimed at a renewed Hellenism, enriched by the best aspects of the Latin culture. Trapezuntius perceived himself as a Greek and as a Christian, believing that someone who is connected and inspired by the Greek past can also be a Christian. In addition, Bessarion held that someone could be Hellene and Orthodox at the same time. All the aforementioned scholars based their views of identity on cultural continuity and history. They felt the need to clarify the bonds that unite the Greeks, namely common history. It is obvious that the basis of the philosophical elites's Hellenitas after the 13th century was not only common language and literary tradition but also historical continuity and cultural otherness, in contrast to Mango's interpretative pattern (Harris 2000, p. 34.; Mango 1981, pp. 48-57). Therefore, commonly held views (Koubourlis 2005, p. 54; Pizanias 2009, p. 14)-according to which Hellenism, as cultural and historical identity, and Christian religion were incompatible in the Post-Byzantine era-are not supported by the writings of the most prominent Greek scholars. Late Byzantine scholars lamented the decline of the former Eastern Roman Empire and sought pride in ancient Greece. Hellenitas was the core concept in their attempt to reshape their national identity. The Greek scholars in the last centuries of Byzantium and after the siege of Constantinople, no matter of their whereabouts, their personal career and their lords, agreed that the shift towards Hellenism would safeguard the existence of the genos. Romanitas and Graecitas remained influential and the debate was heated between proponents of different perspectives on identity. In contrast to commonly held views that the early modern Hellenic identity flourished only in the Latin West and was later introduced in mainland Greece, I suggest that gravitation towards Hellenic identity commenced from the work of Byzantine luminaries who, in some way or another, resided in or were related to the Greek East. Hellenitas is something that cannot be attributed solely, or even mainly, to Byzantine communities in Western Europe. The debate still lasts among Greek intellectuals and the questions posed in Late Byzantium are still open. Hellenitas, from the 15th century onwards, remains a constitutive element of Modern Greek identity. However, Hellenitas is not a process of mere imitation. It is rather a creative reconnection with ancient Greece, enriched by certain Byzantine elements, because its' roots are traced back in Late Byzantium. 
Funding: This research received no external funding.

Conflicts of Interest: The author declares no conflict of interest.

\section{References}

Abrams, Dominic, and Michael A. Hogg, eds. 1990. An introduction to the social identity approach. In Social Identity Theory. Constructive and Critical Advances. London: Harvester-Wheatsheaf, pp. 1-9.

Akışık-Karakullukçu, Aslıhan. 2013. Self and Other in the Renaissance: Laonikos Chalkokondyles and Late Byzantine Intellectuals. Ph.D. dissertation, Harvard University, Cambridge, MA, USA.

Akışık-Karakullukçu, Aslıhan. 2019. A question of audience: Laonikos Chalkokondyles' Hellenism. Byzantinische Zeitschrift 112: 1-30. [CrossRef]

Angelou, Athanasios. 1996. "Who am I?" Scholarios' Answers and the Hellenic Identity. In Philhellene: Studies in Honour of Robert Browning. Edited by Costas N. Constantinides, Nikolaos Panagiotakes, Elisabeth Jeffreys and Athanasios Angelou. Venice: Istituto Ellenico di Studi Bizantini e Postbizantini di Venezia, pp. 1-19.

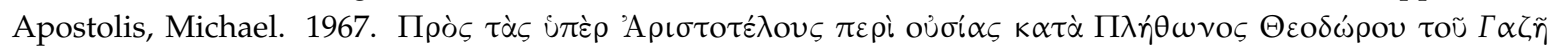
$\dot{\alpha} v \tau \iota \lambda \hat{\eta} \psi \varepsilon \iota \varsigma$-Ad Theodori Gazae pro Aristotele De Substantia Adversus Plethonem Obiectiones. In Kardinal Bessarion als Theologe, Humanist und Staatsmann. V. III. Edited by Ludwig Mohler. Paderborn: Scientia Verlag Aalen, pp. 159-69.

Bargeliotes, Leonidas. 2009. The Enlightenment and the Hellenic 'genos': From Plethon to Vulgaris. Skepsis 20: 44-61.

Beaton, Roderick. 2007. Antique nation? Hellenes on the eve of Greek independence and in twelfth century Byzantium. Byzantine and Modern Greek Studies 31: 76-95. [CrossRef]

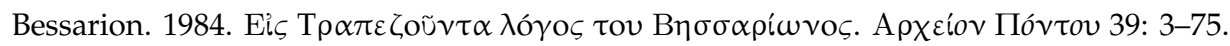

Boissonade, Jean Francois. 1833. Anecdota graeca e codicibus regiis. Paris: In regio typographeo.

Chalkokondyles, Laonicus. 1922-1928. Laonici Chalcocandylae Historiarum Demonstrationes. Edited by Eugenius Darkó. Budapest: Budapestini Sumptibus Academiae litterarum hungaricae.

Constantinidou, Natasha, and Han Lamers, eds. 2019. Receptions of Hellenism in Early Modern Europe. In Receptions of Hellenism in Early Modern Europe. Leiden: Brill, pp. 1-25.

Festa, Nicola. 1898. Theodori Ducae Lascaris Epistulae. Florence: Istituto di studi superiori pratici e di perfezionamento.

Garnsey, Peter. 2009. Gemistus Plethon and Platonic political philosophy. In Transformations of Late Antiquity: Essays for Peter Brown. Edited by Philip Rousseau and Emmanuel Papoutsakis. Aldershot: Ashgate, pp. 327-40.

Geanakoplos, Deno John. 1984. Byzantium: Church, Society, and Civilization Seen through Contemporary Eyes. Chicago: University of Chicago Press.

Geanakoplos, Deno John. 1989. Constantinople and the West: Essays on the Late Byzantine (Palaeologan) and Italian Renaissances and the Byzantine and Roman Churches. Madison: University of Wisconsin Press.

Gellner, Ernest. 1983. Nations and Nationalism. Ithaca: The Cornell University Press.

Gilbert, Felix. 1968. The Venetian Constitution in Florentine Political Thought. In Florentine Studies. Edited by Nicolai Rubenstein. London: Faber and Faber, pp. 463-500.

Grecu, Vasile. 1966. Pseudo-Sprhantzes (Makarios Melissenos). Chronicon sive Maius. In Georgios Sphrantzes. Memorii 1401-1477. Edited by Vasile Grecu. Bucharest: Editura Academiei Republicii Socialiste Romania, pp. 1-618.

Hankins, James. 1990. Plato in the Italian Renaissance. Leiden: Brill.

Harris, Jonathan. 2000. Being a Byzantine after Byzantium: Hellenic identity in Renaissance Italy. Kambos: Cambridge Papers in Modern Greek 8: 25-44.

Hladky, Vojtech. 2014. The Philosophy of Gemistos Plethon: Platonism in Late Byzantium, between Helleneism and Orthodoxy. Abington: Ashgate Publishing.

Hobsbawm, Eric. 2012. Nations and Nationalism Since 1780: Programme, Myth, Reality. Cambridge: Cambridge University Press.

Kaldellis, Anthony. 2007. Hellenism in Byzantium. The Transformations of Greek Identity and the Reception of the Classical Tradition. Cambridge: Cambridge University Press.

Kaldellis, Anthony. 2014a. The Histories, Laonikos Chalkokondyles. Cambridge and London: Harvard University Press.

Kaldellis, Anthony. 2014b. A New Herodotos. Laonikos Chalkokondyles on the Ottoman Empire, the Fall of Byzantium, and the Emergence of the West. Cambridge and London: Harvard University Press. 
Kaldellis, Anthony. 2017. The Social Scope of Roman Identity in Byzantium: An Evidence-Based Approach. Byzantina Symmeikta 27: 173-210. [CrossRef]

Kaldellis, Anthony. 2019. Romanland, Ethnicity and Empire in Byzantium. Cambridge: Harvard University Press.

Karamanolis, George. 2002. Plethon and Scholarios on Aristotle. In Byzantine Philosophy and Its Ancient Sources. Edited by Katerina Ierodiakonou. Oxford: Oxford University Press, pp. 253-82.

Kitromilides, Paschalis. 2009. Paradigm nation: the study of nationalism and the "canonization of Greece". In The Making of Modern Greece: Nationalism, Romanticism, $\mathcal{E}$ the Uses of the Past (1797-1896). Edited by Roderick Beaton and David Ricks. Farnham: Ashgate, pp. 21-32.

Koubourlis, Ioannis. 2005. La Formation de L'Histoire Nationale Grecque. L'Apport de Spyridon Zambélios (1815-1881). In Collection Histoire des Idées 5. Athènes: EIE/INE.

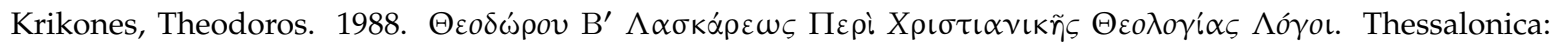
Patriarchal Institute for Patristic Studies.

Kristeller, Paul Oscar. 1972. Byzantine and Western Platonism in the Fifteenth Century. In Renaissance Concepts of Man and other Essays. Edited by Paul Oscar Kristeller. New York: Harper \& Row, pp. 86-109.

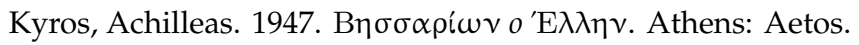

Lagarde, Bernardette. 1973. Le De differentiis de Pléthon d'après l'autographe de la Marcienne. Byzantion 43: 312-43.

Lamers, Han. 2015. Greece Reinvented: Transformations of Byzantine Hellenism in Renaissance Italy. Leiden: Brill.

Lampros, Spyridon. 1910. A $\rho \gamma \cup \rho o \pi o u ́ \lambda \varepsilon \iota \alpha$. Athens: P. D. Sakellariou.

Lampros, Spyridon. 1926. Isidor of Kiev, Panegyricus ad Manuelem et Joannem VIII Palaeologum. П $\alpha \lambda \alpha\left\llcorner{ }_{1} \gamma^{\gamma \varepsilon}\llcorner\alpha\right.$

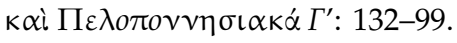

Laurent, Vitalien. 1971. Les "Mémoires" du Grand Ecclésiarque de l' Eglise de Constantinople Sylvestre Syropoulos sur le concile de Florence. Paris: Institut Francais des Études Byzantines.

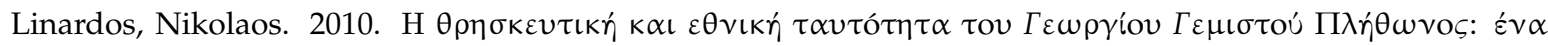

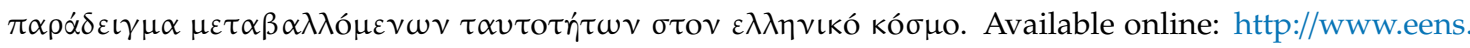
org/EENS_congresses/2010/Linardos_Nikolaos.pdf (accessed on 30 October 2015).

Livanios, Dimitris. 2008. The Quest for Hellenism: Religion, Nationalism, and Collective Identities in Greece, 1453-1913. In Hellenisms. Culture, Identity and Ethnicity from Antiquity to Modernity. Edited by Katerina Zacharia. Aldershot: Ashgate Variorum, pp. 237-69.

Livanos, Christopher. 2004. The Conflict between Scholarios and Plethon: Religion and Communal Identity in Early Modern Greece. In Modern Greek Literature: Critical Essays. Edited by Gregory Nagy and Anna Stavrakopoulou. London and New York: Routledge, pp. 23-40.

Livanos, Christopher. 2006. Greek Tradition and Latin Influence in the Work of George Scholarios: Alone against All of Europe. Piscataway: Gorgias Press.

Magdalino, Paul, ed. 1991. Hellenism and Nationalism in Byzantium. In Tradition and Transformation in Medieval Byzantium. Aldershot: First Publication Variorum, part XIV. pp. 1-29.

Mango, Cyril. 1981. Discontinuity with the Classical Past in Byzantium. In Byzantium and the Classical Tradition. Edited by Margaret Mullett and Roger Scott. Birmingham: Centre for Byzantine Studies, University of Birmingham, pp. 48-57.

Mavroudi, Maria. 2013. Plethon as a Subversive and His Reception in the Islamic World. In Power and Subversion in Byzantium. Edited by Dimiter Angelov and Michael Saxby. Publications of the Society for the Promotion of Byzantine Studies 17. Farnham: Ashgate Variorum, pp. 177-204.

Metochites, Theodoros. 1996. Theodorus Metochites on Philosophic Irony and Greek History. Edited by Panagiotis A. Agapitos, Karin Hult and Ole L. Smith. Nicosia: Department of Greek Studies, Philosophy and History, University of Cyprus.

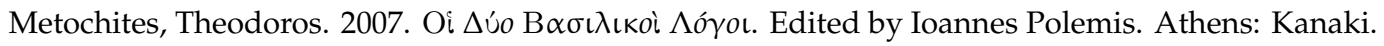

Migne, Jacques Paul. 1866a. Patrologiae Cursus Completes, Series Graeca 160. Paris: Migne.

Migne, Jacques Paul. 1866b. Patrologiae Cursus Completes, Series Graeca 161. Paris: Migne.

Mioni, Elpidio. 1973. Introduzione alla Paleografia Greca. Padua: Liviana.

Mohler, Ludwig. 1923-1942. Kardinal Bessarion als Theologe, Humanist, und Staatsmann. Paderborn: Scientia Verlag Aalen.

Monfasani, John. 1976. George of Trebizond: A Biography and a Study of His Rhetoric and Logic. Leiden: Brill. 
Monfasani, John. 1984. Collectanea Trapezuntiana, Texts, Documents, and Bibliographies of George of Trebizond. Binghamton and New York: Medieval and Renaissance Texts and Studies, in Conjunction with The Renaissance Society of America.

Monfasani, John. 1992. Platonic Paganism in the Fifteenth Century. In Reconsidering the Renaissance. Edited by Mario Di Cesare. Binghamton: Center for Medieval and Early Renaissance Studies, pp. 45-61.

Monfasani, John. 2002a. Nicholas of Cusa, the Byzantines, and the Greek Language. In Nicolaus Cusanus zwischen Deutschland und Italien. Edited by Martin Thurner. Berlin: Akademie Verlag, pp. 215-52.

Monfasani, John. 2002b. Marsilio Ficino and the Plato-Aristotle Controversy. In Marsilio Ficino: His Theology, His Philosphy, His Legacy. Edited by Michael J. B. Allen and Valery Rees. Leiden: Brill, pp. 189-202.

Myrogiannis, Stratos. 2012. The Emergence of a Greek Identity (1700-1821). Newcastle: Cambridge Scholars Publishing.

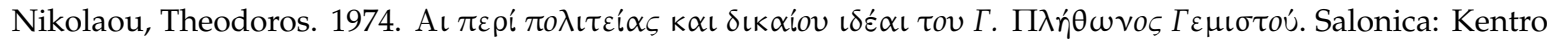
Byzantinon Ereunon.

Page, Gill. 2008. Being Byzantine. Greek Identity before the Ottomans. Cambridge: Cambridge University Press.

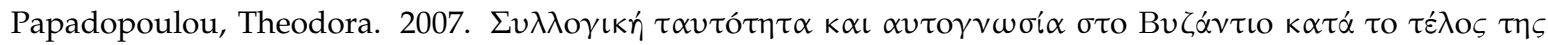
$\mu \varepsilon \sigma o \beta v \zeta \alpha v \tau \iota v \eta \dot{s} \pi \varepsilon \rho \iota \delta_{\delta}$ ov. Ph.D. thesis, Ionian University, Corfu, Greece.

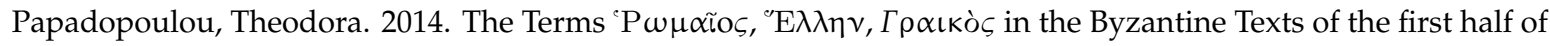
the 13th century. Byzantina Symmeikta 24: 157-76. [CrossRef]

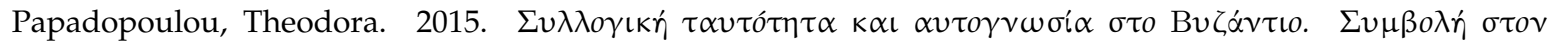

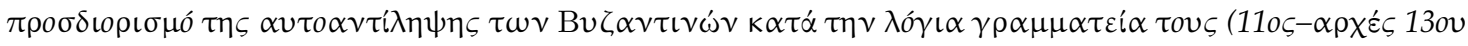
$\alpha$ L.). Athens: Syllogos pros diadosin ofelimon biblion.

Patrinelis, Christos. 1972. An Unknown Discourse of Chrysoloras addressed to Manuel II Palaeologus. Greek, Roman and Byzantine Studies XIII: 497-502.

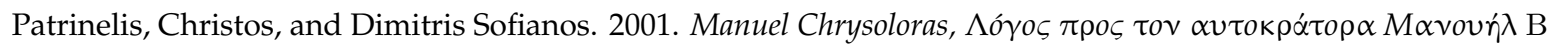
$\Pi \alpha \lambda \alpha \iota$ เó $\gamma o$. Athens: Academy of Athens.

Peritore, Patrick. 1977. The Political Thought of Gemistos Plethon: A Renaissance Byzantine Reformer. Polity 10: 168-91. [CrossRef]

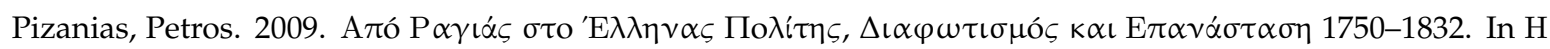

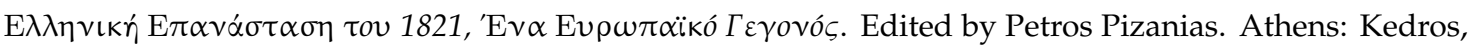
pp. 13-78.

Pletho. 1926a. Address to the emperor Manuel on affairs in the Peloponnese. Edited by Spryros Lambros. In Palaiologeia kai Peloponnisiaka III. Athens: ГРНГОРІА $\Delta \mathrm{H} \Sigma$, pp. 246-65.

Pletho. 1926b. Funeral oration on Helen Palaiologina. Edited by Spryros Lambros. In Palaiologeia kai Peloponnisiaka III. Athens: ГРНГОРІА $\triangle \mathrm{H} \Sigma$, pp. 266-80.

Priscus. 1979. Prisci Panitae fragmenta. Edited by Fritz Bornmann. Florence: Le Monnier.

Rapp, Claudia. 2008. Hellenic identity, Romanitas, and Christianity in Byzantium. In Hellenisms. Culture, Identity and Ethnicity from Antiquity to Modernity. Edited by Katerina Zacharia. Aldershot: Ashgate Variorum, pp. 127-47.

Romano, Roberto. 1974. Pseudo-Luciano, Timarione: testo critico, introduzione, traduzione, commentario e lessico, Byzantina et neo-hellenica neapolitana 2. Naples: Università di Napoli, Cattedra di filologia bizantina.

Runciman, Steven. 1985. The Great Church in Captivity. Cambridge: Cambridge University Press.

Schmitt, John. 1904. The Chronicle of Morea. London: Methuen.

Scholarius, Georgius. 1928. Oeuvres completes de Gennade Scholarios. Edited by Louis Petit, Martin Jugie and Xenophon Siderides. Paris: Maison de la Bonne Presse, vol. I.

Scholarius, Georgius. 1930. Oeuvres completes de Gennade Scholarios. Edited by Louis Petit, Martin Jugie and Xenophon Siderides. Paris: Maison de la Bonne Presse, vol. III.

Scholarius, Georgius. 1935. Oeuvres completes de Gennade Scholarios. Edited by Louis Petit, Martin Jugie and Xenophon Siderides. Paris: Maison de la Bonne Presse, vol. IV.

Scholarius, Georgius. 1936. Oeuvres completes de Gennade Scholarios. Edited by Louis Petit, Martin Jugie and Xenophon Siderides. Paris: Maison de la Bonne Presse, vol. VII.

Ševčenko, Igor. 1961. The Decline of Byzantium Seen Through the Eyes of Its Intellectuals. Dumbarton Oaks Papers 15: 167-86. [CrossRef] 
Siniossoglou, Niketas. 2011. Radical Platonism in Byzantium: Illumination and Utopia in Gemistos Plethon. Cambridge: Cambridge University Press.

Siniossoglou, Niketas. 2014. Plethon and the Philosophy of Nationalism. In Georgios Gemistos Plethon, The Byzantine and the Latin Renaissance. Edited by Paul Richard Blum and Joseph Matula. Olomouc: Univerzita Palackého v Olomouci, pp. 415-31.

Smarnakis, Ioannis. 2015. Rethinking Roman Identity after the Fall (1453): Perceptions of 'Romanitas' by Doukas and Sphrantzes. Byzantina Symmeikta 25: 211-34. [CrossRef]

Smith, Anthony. 1991. National Identity. London: Penguin.

Smith, Anthony. 1995. Gastronomy or Geology? The Role of Nationalism in the Reconstruction of Nations. Nations and Nationalism 1: 3-23. [CrossRef]

Smith, Anthony. 2004. The Antiquity of Nations. Cambridge: Polity Press.

Smith, Anthony. 2005. Nationalism in Early Modern Europe. History and Theory 44: 404-15. [CrossRef]

Smith, Anthony. 2009. Ethno-Symbolism and Nationalism: A Cultural Approach. Abingdon: Routledge.

Smythe, C. Dion. 1996. Byzantine identity and labelling theory. In XIX International Congress of Byzantine Studies. Edited by Karsten Fledelius and Peter Schreiner. Copenhagen: Major Papers, pp. 26-36.

Stefec, Rudolf. 2010. Aus der literarischen Werkstatt des Michael Apostoles. Jahrbuch der Österreichischen Byzantinistik 60: 129-48. [CrossRef]

Steiris, Georgios. 2015. Argyropoulos John. In Encyclopedia of Renaissance Philosophy. Edited by Marco Sgarbi. Dordrecht: Springer. Available online: http://link.springer.com/referenceworkentry/10.1007/978-3-319-028484_19-1 (accessed on 30 January 2020).

Steiris, Georgios. 2016. Byzantine Philosophers of the 15th Century on Identity and Otherness. In The Problem of Modern Greek Identity: from the Ecumene to the Nation-State. Edited by Georgios Steiris, Sotiris Mitralexis and Georgios Arabatzis. Newcastle upon Tyne: Cambridge Scholars Publishing, pp. 173-99.

Steiris, Georgios. 2017. Pletho, Scholarios and the Arabic philosophy. In Never the Twain Shall Meet: Latins and Greeks Learning from Each Other in Byzantium. Edited by Denis Searby. Berlin and New York: De Gruyter, pp. 309-34.

Steiris, Georgios, Sotiris Mitralexis, and Georgios Arabatzis, eds. 2016. The Problem of Modern Greek Identity, From the Ecumene to the Nation State. Newcastle upon Tyne: Cambridge Scholars Publishing.

Stouraitis, Ioannis. 2014. Roman Identity in Byzantium: A Critical Approach. Byzantinische Zeitschrift 107: 175-220. [CrossRef]

Stouraitis, Ioannis. 2017. Reinventing Roman ethnicity in high and Late Medieval Byzantium. Medieval Worlds 5: 70-94. [CrossRef]

Stouraitis, Ioannis. 2018. Byzantine Romanness: From geopolitical to ethnic conceptions. In Transformations of Romanness in the Early Middle Ages: Early Medieval Regions and Identities (Millennium Studies 71). Edited by Walter Pohl, Clemens Gantner, Cinzia Grifoni and Marianne Pollheimer-Mohaupt. Berlin: De Gruyter, pp. 123-39.

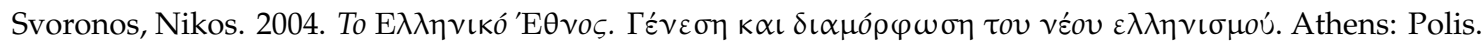

Syros, Vasileios. 2010. Between Chimera and Charybdis: Byzantine and Post-Byzantine Views on the Political Organization of the Italian City-States. Journal of Early Modern History 14: 451-504. [CrossRef]

Tevzadze, Natia. 1994. National identity and national consciousness. Journal History of European Ideas 19: 437-40. [CrossRef]

Trapezuntius, Georgius. 1523. Comparationes phylosophorum Aristotelis et Platonis. Venice: Iacobus Pentius de Leuco. Tzetzes, Joannes. 1972. Epistulae. In Ioannis Tzetzae epistulae. Edited by Pietro Luigi Leone. Leipzig: Teubner, pp. 1-84.

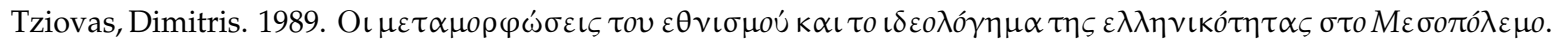
Athens: Odysseas.

Vacalopoulos, Apostolos. 1970. Origins of the Greek Nation: The Byzantine Period, 1204-1461. New Brunswick: Rutgers University Press.

Vryonis, Spyros. 1978. Recent scholarship on continuity and discontinuity of culture: Classical Greeks, Byzantines, Modern Greeks. In The 'Past' in Medieval and Modern Greek Culture. Edited by Spyros Vryonis. Malibu: Undena Publications, pp. 237-56. 
Vryonis, Spyros. 1991. Byzantine Cultural Self-Consciousness in the Fifteenth Century. In The Twilight of Byzantium: Aspects of Cultural and Religious History in the Late Byzantine Empire. Edited by Sloboda Curcic and Doula Mouriki. Princeton: Princeton University Press, pp. 5-14.

Vryonis, Spyros. 1999. Greek Identity in the Middle Ages. Études Balkaniques-Cahiers Pierre Belon 6: 19-36. [CrossRef]

Webb, Ruth. 1989. The Nomoi of Gemistos Plethon in the light of Plato's Laws. Journal of the Warburg and Courtauld Institutes 52: 214-19. [CrossRef]

Woodhouse, Christopher Montague. 1986. George Gemistos Plethon: The Last of the Hellenes. Oxford: Oxford University Press.

Zakythinos, Denis. 1932. Le Despotat Grec de Morée, II. Paris: Les Belles Lettres.

(C) 2020 by the author. Licensee MDPI, Basel, Switzerland. This article is an open access article distributed under the terms and conditions of the Creative Commons Attribution (CC BY) license (http://creativecommons.org/licenses/by/4.0/). 